\title{
Integrated Nutrient Management for Sustainable Maize (Zea mays L.) Production in Acidic Soil of Senapati District, Manipur, India
}

\author{
Haribhushan Athokpam ${ }^{1}$, R.S. Telem ${ }^{1}$ and S.H. Wani ${ }^{2}$ \\ ${ }^{1}$ Farm Science Centre (KVK), Senapati District, P.O. Kangpokpi, Manipur - 795129, India \\ ${ }^{2}$ Division of Plant Breeding and Genetics, SKUAST-K, Shalimar Srinagar-190025, \\ Kashmir, India \\ *Corresponding author
}

\begin{tabular}{|c|c|}
\hline & A B S T R A C T \\
\hline & \multirow{5}{*}{$\begin{array}{l}\text { Field experiment was conducted at Krishi Vigyan Kendra- Senapati, Manipur for two } \\
\text { consecutive kharif seasons of years } 2014 \text { and } 2015 \text { to find out most efficient and economic } \\
\text { combination of different organic and inorganic sources of nutrients to increase the } \\
\text { productivity of maize (Zea mays L.) without deteriorating the soil qualities. Application of } \\
100 \% \text { NPK recommended dose of fertilizers in combination with biofertilizers } \\
\text { (Azotobacter) and incorporation of vermicompost @ } 5 \text { t/ha improved soil physico- } \\
\text { chemical properties (viz. decrease in acidic } \mathrm{pH} \text { ). This was also responsible for improving } \\
\text { the nutrient status of soil in respect of available } \mathrm{N} \text { and available } \mathrm{P}_{2} \mathrm{O}_{5} \text { which were } \\
\text { increased by } 87 \mathrm{~kg} / \mathrm{ha} \text { and } 14.08 \mathrm{~kg} / \mathrm{ha} \text {, respectively over the initial nutrient status of soil. } \\
\text { Maize grain yield was also increased by } 181.90 \% \text { (under application of } 100 \% \mathrm{NPK}+ \\
\text { vermicompost @ } 5 \mathrm{t} \mathrm{ha}^{-1} \text { ) over control. Combined use of vermicompost along with } \\
\text { inorganic fertilizers were efficiently used by maize crop and had maximum values of yield } \\
\text { attributes, yields as well as highest average net return of about Rs } 57,716 / \mathrm{ha} \text { and also } \\
\text { maintained soil fertility. }\end{array}$} \\
\hline & \\
\hline $\begin{array}{l}\text { Biofertilizers, } \\
\text { Maize, } \\
\text { Physico-Chemical } \\
\text { properties, } \\
\text { Vermicompost. }\end{array}$ & \\
\hline Article Info & \\
\hline $\begin{array}{l}\text { Accepted: } \\
\text { 14 June } 2017 \\
\text { Available Online: } \\
\text { 10 July } 2017\end{array}$ & \\
\hline
\end{tabular}

\section{Introduction}

The NER of India has geographical area of 26.3 million hectors and population of 45 million. Almost $85 \%$ of soils in this region are moderate to strongly acidic (Das et al., 2016). Maize is globally the top ranking cereal in potential grain productivity. In India, maize is the third most important food crops after rice and wheat. Maize (Zea mays L.) is becoming very popular cereal crop in India because of the increasing market price and high production potential of hybrid varieties in both irrigated as well as rainfed conditions. Maize has high production potential compared to any other cereal crop. Hence it is called as 'miracle crop' and also as 'queen of cereals because it has the highest genetic yield potential among the cereals. Maize is a crop par excellence for food, feed and industrial utilization.

The productivity of maize is largely dependent on its nutrient management. Maize can be grown successfully in variety of soils ranging from loamy sand to clay loam. However, soils with good organic matter content having high water holding capacity with neutral $\mathrm{pH}$ are considered good for higher productivity. The average productivity 
of Maize in the north-east hill region of India is very low $(1.50 \mathrm{t} / \mathrm{ha})$ mainly owing to cultivation under nutrient-starved condition Continuous use of only chemical fertilizers in intensive cropping system is leading to imbalance of nutrients in soil, which has an adverse effect on soil health and also on crop yields. Over reliance on use of chemical fertilizers has been associated with declines in soil physical and chemical properties and crop yield (Hepperly et al., 2009) and significant land problems, such as soil degradation due to over exploitation of land and soil pollution caused by high application rates of fertilizers and pesticide application (Singh, 2000). But, use of organics alone does not result in spectacular increase in crop yields, due to their low nutrient status. The conjunctive application of organics with inorganic sources of nutrients reduces the dependence on chemical inputs (Vanlanwe et al., 2002). Integrated nutrient management (INM) is a flexible approach to minimize the use of chemical fertilizer along with maximization of their efficiency and farmer's profit. The vermicompost along with inorganic fertilizers were efficiently used by maize crop for their growth and development and also maintained soil fertility and increased yield of the crop (Sanjivkumar, 2014). Therefore, Integrated Nutrient Supply/management (INS) aims at maintenance or adjustment of soil fertility and of plant nutrient supply to an optimum level for sustaining the desired crop productivity through optimization of benefit from all possible sources of plant nutrients in an integrated manner (Roy and Ange, 1991). Highest productivity of crops in sustainable manner without deteriorating the soil and other natural resources could be achieved only by applying appropriate combination of different organic manures and inorganic fertilizers (Chandrashekara et al., 2000). Integrated use of organic and inorganic fertilizers not only recorded significantly greater root-shoot dry matter but also accelerated their growth compared to inorganic fertilizer application (Ghosh et al., 2003).

\section{Materials and Methods}

A field experiment was conducted during kharif season of 2013-14 \& 2014-15 at farmers field of Krishi Vigyan Kendra Senapati, Manipur, India with objective to establish Integrated nutrient management for increasing production of maize with sustainability and residual fertility status in acidic soil of Senapati District, Manipur. The geographical area of the district is 3271 sq. $\mathrm{km}$ with $14.56 \%$ of the total geographical area of the state. The average temperature ranges from $4{ }^{\circ} \mathrm{C}$ to $32^{\circ} \mathrm{C}$ and average annual rainfall varies from 671 to $1454 \mathrm{~mm}$. It is located between $24^{\circ} 30^{\prime} \mathrm{N}$ latitude and $93^{\circ} 30^{\prime} \mathrm{E}$ longitude over the globe. The altitude of the district ranges from 800 to $4000 \mathrm{~m}$ above MSL. Senapati district has alluvium, lateritic black regur and ferruginous type of soil (Anonymous, 2009). The soil of the experimental site was clayey soil (Fluvaquentic Humaquepts) of $18.10 \%$ sand, $14.60 \%$ silt and $67.30 \%$ clay, strongly acidic (pH 5.10) in reaction, medium in available nitrogen (412 $\mathrm{Kg} \mathrm{ha}^{-1}$ ), phosphorus (20 kg ha${ }^{1}$ ) and potassium $\left(128 \mathrm{~kg} \mathrm{ha}^{-1}\right)$, low in sulphur $\left(0.047 \mathrm{mg} \mathrm{kg}^{-1}\right)$ while high in zinc $(3.35 \mathrm{mg}$ $\mathrm{kg}^{-1}$ ) (Table 1).

The twelve treatments, viz. $100 \%$ NPK, 100 $\% \mathrm{NPK}+\mathrm{Zn}, 100 \% \mathrm{NPK}+\mathrm{S}+\mathrm{Zn}, 100 \%$ $\mathrm{NPK}+\mathrm{S}, 100 \% \mathrm{NPK}+$ seed treatment with Azotobacter, vermicompost @ 5 tonnes /ha + $100 \%$ NPK (excluding NPK content of vermicompost ), $100 \% \mathrm{NPK}+$ vermicompost @ 5 tonnes /ha, vermicompost @ 10 tonnes /ha, $150 \%$ NPK, $100 \%$ NP, 100\% N and absolute control were replicated four times in randomized block design. The sources used for applying $\mathrm{N}, \mathrm{P}$ and $\mathrm{k}$ were urea, diammonium phosphate (adjusted for its $\mathrm{N}$ 
content) and muriate of potash, respectively. Gypsum and zinc sulphate $\left(\mathrm{ZnSO}_{4} .7 \mathrm{H}_{2} \mathrm{O}\right)$ were used to supply $\mathrm{S}$ and $\mathrm{Zn}$. The other sources of nutrients were vermicompost and biofertilizer (Azotobacter sp.). The dose of the NPK for maize was worked out according to the soil test fertilizer recommendation. The $100 \%$ NPK dose in $\mathrm{Kg} \mathrm{ha}^{-1}$ worked out was 80:60:40 for maize crop. The doses for sulphur and zinc were framed as $40 \mathrm{~kg} \mathrm{~S} \mathrm{ha}^{-1}$ and $5 \mathrm{~kg} \mathrm{Zn} \mathrm{ha}^{-1}$, respectively while vermicompost was applied as per the treatments. Maize local variety was sown at the seed rate of $25 \mathrm{~kg} \mathrm{ha}^{-1}$ at the inter row of $60 \mathrm{~cm}$ and plant to plant spacing of $20 \mathrm{~cm}$. Soil samples, 0-15 cm depth from each plot were drawn after harvest of the crop and air dried in shade, ground with wooden pestle and mortar and passed through $2 \mathrm{~mm}$ sieve and analysed for $\mathrm{N}, \mathrm{P}_{2} \mathrm{O}_{5}$ and $\mathrm{K}_{2} \mathrm{O}$ as per standard procedures. Statistical analysis of the data was carried out using standard analysis of variance (Panse and Sukhatme, 1989).

\section{Results and Discussion}

The data presented in table 2 indicate that all the treatments improved the available NPK status over unfertilized control after harvest of maize crop. Maximum available nitrogen (499.00 kg ha ${ }^{-1}$ ), phosphorus (34.08 kg ha ${ }^{-1}$ ) was observed under treatment receiving 100 $\% \mathrm{NPK}+$ Vermicompost $5 \mathrm{t} \mathrm{ha}^{-1}$ while maximum potassium (338 $\mathrm{kg} \mathrm{ha}^{-1}$ ) was observed under the treatment receiving $150 \%$ NPK. Tetarwal et al., (2011) also observed similar results in respect of $\mathrm{N}, \mathrm{P}$ and $\mathrm{K}$ status of soil (Fig. 1).

The data (Table 3) show that application of only $100 \%$ recommended N significantly increased weight of cob but the efficiency was further improved by adding phosphorus and potassium to the fertilization schedule. Data further show that nutrient stress (unfertilized control) had minimum cob weight $(58.00 \mathrm{~g})$ and all the nutrient application treatments resulted in significantly higher cob weight. The heaviest cob $\left(131.10 \mathrm{~g} \mathrm{cob}^{-1}\right)$ was produced under the application of $100 \%$ NPK + Vermicompost $5 \mathrm{t} \mathrm{ha}^{-1}$. It clearly evidence from the research finding that application of plant nutrients in the form of chemical fertilizer, organic sources or integrated way resulted in significantly higher cob length as compared with unfertilized control.

Table.1 Some major physical and chemical characteristics of the soil in experimental site

\begin{tabular}{|l|c|}
\hline \multicolumn{1}{|c|}{ Soil characteristic } & Value \\
\hline $\mathrm{pH}$ & 5.10 \\
\hline Organic carbon $\left(\mathrm{g} \mathrm{kg}^{-1}\right)$ & 21.3 \\
\hline Available $\mathrm{N}\left(\mathrm{kg} \mathrm{ha}^{-1}\right)$ & 412 \\
\hline Available $\mathrm{P}_{2} \mathrm{O}_{s}\left(\mathrm{~kg} \mathrm{ha}^{-1}\right)$ & 20 \\
\hline Available $\mathrm{K}_{2} \mathrm{O}\left(\mathrm{kg} \mathrm{ha}^{-1}\right)$ & 128 \\
\hline Sulphur $\left(\mathrm{mg} \mathrm{kg}^{-1}\right)$ & 0.047 \\
\hline Zinc $\left(\mathrm{mg} \mathrm{kg}^{-1}\right)$ & 3.35 \\
\hline Clay $(\%)$ & 67.30 \\
\hline Silt $(\%)$ & 14.60 \\
\hline Sand $(\%)$ & 18.10 \\
\hline
\end{tabular}


Table.2 Effect of integrated nutrient management practices on nutrients status of soil after harvesting of maize crop

\begin{tabular}{|c|c|c|c|c|}
\hline Treatments & pH & $\begin{array}{l}\text { Available } \\
\mathbf{N} \\
\left(\mathrm{kg} \mathrm{ha}^{-1}\right)\end{array}$ & $\begin{array}{c}\text { Available } \\
\mathrm{P}_{2} \mathrm{O}_{5} \\
\left(\mathrm{~kg} \mathrm{ha}^{-1}\right)\end{array}$ & $\begin{array}{c}\text { Available } \\
\mathrm{K}_{2} \mathrm{O} \\
\left(\mathrm{kg} \mathrm{ha}^{-1}\right)\end{array}$ \\
\hline $100 \% \mathrm{NPK}$ & 4.98 & 390 & 28.00 & 222 \\
\hline $100 \% \mathrm{NPK}+\mathrm{Zn}$ & 4.99 & 399 & 27.50 & 247 \\
\hline $100 \% \mathrm{NPK}+\mathrm{S}+\mathrm{Zn}$ & 5.01 & 376 & 26.00 & 228 \\
\hline $100 \% \mathrm{NPK}+\mathrm{S}$ & 5.04 & 382 & 27.00 & 234 \\
\hline $\begin{array}{l}100 \quad \% \\
\text { Azotobacter }\end{array}$ & 5.05 & 412 & 29.00 & 253 \\
\hline $\begin{array}{l}\text { Vermicompost } 5 \mathrm{tha}^{-1}+ \\
100 \% \text { NPK (- NPK of } \\
\text { Vermicompost) }\end{array}$ & 5.6 & 435 & 28.77 & 278 \\
\hline $\begin{array}{l}100 \% \text { NPK } \\
\text { Vermicompost } 5 \mathrm{t} \mathrm{ha}^{-1}\end{array}$ & 5.7 & 499 & 34.08 & 266 \\
\hline Vermicompost $10 \mathrm{t} \mathrm{ha}^{-1}$ & 5.7 & 392 & 30.50 & 250 \\
\hline $150 \% \mathrm{NPK}$ & 5.2 & 483 & 27.95 & 338 \\
\hline $100 \% \mathrm{NP}$ & 4.99 & 377 & 28.00 & 167 \\
\hline $100 \% \mathrm{~N}$ & 5.01 & 384 & 21.60 & 176 \\
\hline Control & 5.0 & 303 & 19.00 & 120 \\
\hline
\end{tabular}

Table.3 Effect of integrated nutrient management practices on Yield parameters of maize

\begin{tabular}{|c|c|c|c|c|c|}
\hline Treatments & $\begin{array}{l}\text { Weight of } \\
\operatorname{Cob}^{-1}(\mathrm{~g})\end{array}$ & $\begin{array}{l}\text { Weight } \\
\text { of grain } \\
\mathrm{Cob}^{-1} \\
\text { (g) }\end{array}$ & $\begin{array}{l}\text { Test } \\
\text { weight } \\
\text { (g) }\end{array}$ & $\begin{array}{l}\text { Cob } \\
\text { length } \\
(\mathrm{cm})\end{array}$ & $\begin{array}{l}\text { Grain } \\
\text { yield } \\
\left(\mathrm{q} \mathrm{ha} \mathrm{ha}^{-1}\right)\end{array}$ \\
\hline $100 \% \mathrm{NPK}$ & 117.85 & 82.87 & 192.05 & 17.88 & 32.00 \\
\hline $100 \% \mathrm{NPK}+\mathrm{Zn}$ & 118.15 & 83.00 & 192.92 & 17.48 & 32.24 \\
\hline $100 \% \mathrm{NPK}+\mathrm{S}+\mathrm{Zn}$ & 123.19 & 84.18 & 187.20 & 18.10 & 35.40 \\
\hline $100 \% \mathrm{NPK}+\mathrm{S}$ & 119.23 & 83.45 & 186.88 & 17.00 & 33.09 \\
\hline $100 \%$ NPK + Azotobacter & 118.80 & 84.22 & 189.11 & 17.14 & 32.60 \\
\hline $\begin{array}{l}\text { Vermicompost 5t ha }{ }^{-1}+100 \\
\% \text { NPK }\end{array}$ & 118.50 & 87.54 & 195.22 & 17.58 & 35.10 \\
\hline (-NPK of Vermicompost) & 56.00 & & & & \\
\hline $\begin{array}{l}100 \quad \% \quad \text { NPK } \\
\text { Vermicompost } 5 \mathrm{t} \mathrm{ha}^{-1}\end{array}$ & 131.10 & 92.25 & 198.14 & 18.85 & 38.00 \\
\hline Vermicompost $10 \mathrm{t} \mathrm{ha}^{-1}$ & 110.01 & 81.85 & 183.00 & 15.60 & 26.80 \\
\hline $150 \% \mathrm{NPK}$ & 123.00 & 88.12 & 189.00 & 18.00 & 35.25 \\
\hline $100 \% \mathrm{NP}$ & 100.05 & 74.20 & 177.12 & 16.28 & 28.30 \\
\hline $100 \% \mathrm{~N}$ & 97.00 & 61.15 & 173.40 & 15.14 & 18.69 \\
\hline Control & 58.00 & 32.67 & 162.48 & 13.74 & 13.48 \\
\hline
\end{tabular}


Table.4 Economic impact for the application of 100\% NPK+ Vermicompost @ $5 \mathrm{t} / \mathrm{ha}$

\begin{tabular}{|l|l|l|l|l|}
\hline S1.No. & $\begin{array}{l}\text { Average cost of cultivation } \\
\text { (Rs /ha) }\end{array}$ & $\begin{array}{l}\text { Average gross } \\
\text { return } \\
\text { (Rs/ha) }\end{array}$ & $\begin{array}{l}\text { Average net return } \\
\text { (Profit) } \\
\text { (Rs/ha) }\end{array}$ & B.C Ratio \\
\hline 1. & 94,284 & 152,000 & 57,716 & $1.61: 1$ \\
\hline
\end{tabular}

Fig.1 Some major physical and chemical characteristics of the soil in experimental site

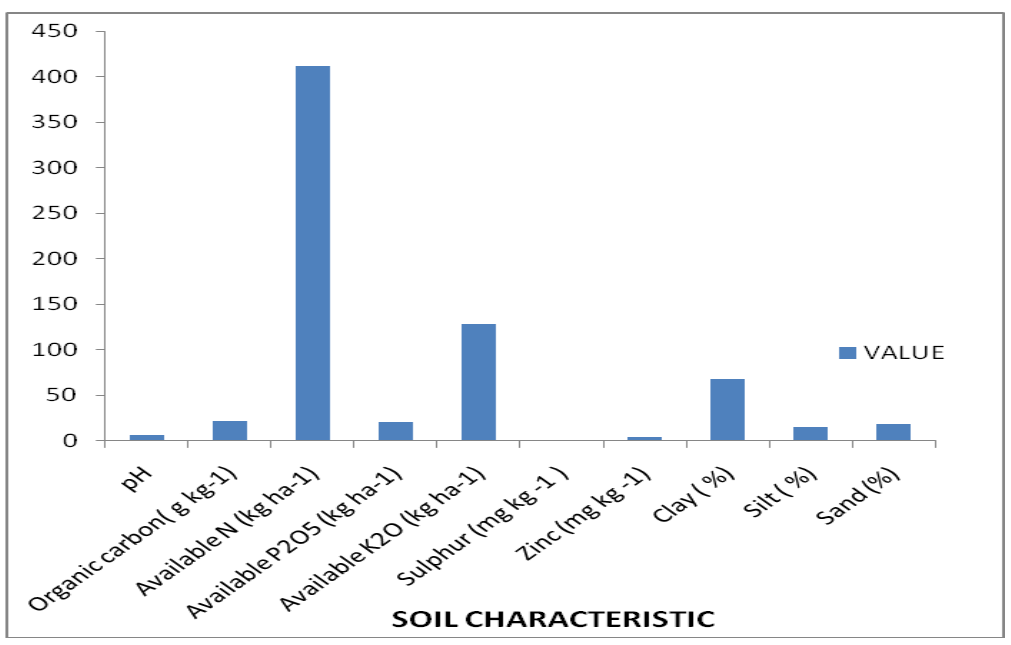

Maximum cob length $(18.85 \mathrm{~cm})$ was found when crop was supplied with $100 \%$ NPK + Vermicompost $5 \mathrm{t} \mathrm{ha}^{-1}$. Maximum weight of grains $\operatorname{cob}^{-1}$ (92.25 g) was observed when crop was supplied with $100 \%$ NPK + Vermicompost $5 \mathrm{t} \mathrm{ha}^{-1}$ which was at par with seed treatment with Azotobacter, Vermicompost 5t ha ${ }^{-1}+100$ $\%$ NPK (-NPK of Vermicompost) and $150 \%$ NPK. The 1000 grain weight of maize was significantly improved by application of various nutrients through different sources. Maximum 1000 grain weight ( $198.14 \mathrm{~g}$ ) was produced under the application of $100 \%$ NPK + Vermicompost $5 \mathrm{t} \mathrm{ha}^{-1}$ (Table 3). The highest grain yield (38.00 $\left.\mathrm{q} \mathrm{ha}^{-1}\right)$ was produced by application of $100 \%$ NPK + Vermicompost $5 \mathrm{t}$ $\mathrm{ha}^{-1}$ and its performance was at par with $100 \%$ $\mathrm{NPK}+\mathrm{S}+\mathrm{Zn}$ and $150 \%$ NPK (Table 3). The treatment receiving $100 \%$ NPK and its combination with $\mathrm{Zn}, \mathrm{S}, \mathrm{Zn}+\mathrm{S}$, Azotobacter seed treatment and Vermicompost $5 \mathrm{t} \mathrm{ha}^{-1}+100$ $\%$ NPK (- NPK of Vermicompost) showed statistically equivalent results in increasing grain yield over the other treatments. Though application of $100 \% \mathrm{~N}, 100 \% \mathrm{NP}$, and Vermicompost $10 \mathrm{t} \mathrm{ha}^{-1}$ increased the yield significantly over control but provided inferior results in comparison to aforesaid treatments. Similarly application of Vermicompost $10 \mathrm{t} \mathrm{ha}^{-1}$ and $100 \% \mathrm{~N}$ alone were statistically at par with other but statistically superior over unfertilized control but provided inferior results in comparison to aforesaid treatments (Table 4). The increase in yield varied from 13.48 to $78 \mathrm{q}$ $\mathrm{ha}^{-1}$.

\section{Acknowledgements}

The authors are especially gratefully to ATARI, Zone-III, for their valuable suggestions and financial support during the course of investigation

In conclusion, INM practice including vermicompost and recommended dose of NPK showed its best results with respect to yield parameters like number of grains per cob, cob length, 1000 seed weight, weight of the cob and 
yield. The present study concluded that vermicompost along with inorganic NPK fertilizers and Biofertilizers (Azotobacter) were efficiently used by maize crop for their growth and development and also maintained soil fertility and increased yield of the crop.

From the two years experimentation it can be concluded that, application of $100 \% \mathrm{NPK}+$ vermicompost @ $5 \mathrm{tha}^{-1}$ is the best combination of organic and inorganic fertilizers for increasing productivity of maize with sustainability. This treatment is also responsible for improving physico- chemical properties and nutrient status of soil as well as highest average net return of about Rs 57,716/ha. Thus the combined use of organic manure and chemical fertilizer holds great promise in meeting the growing nutrient demands of intensive agriculture and maintaining the crop productivity at higher levels with overall improvement of soil fertility.

\section{References}

Anonymous. 2009. Baseline Survey of Minority Concentrated Districts. District Report Senapati. Study Commissioned by Ministry of Minority Affairs Government of India. 14pp.

Chandrashekara, C.P., Harlapur, S.I., Murlikrishna, S. and Girijesh, G.K. 2000. Response of maize (Zea maize L.) to organic manures with inorganic fertilizers, Karnataka J. Agric. Sci., 13(1): 144-146.

Das, A., Ramkrushna, G.I., Makdoh, B., Sarkar, D., Layek, J., Mandal, S. and Lal, R. 2016. Managing Soils of the Lower Himalayas. Encyclopedia of Soil Sci., 3rd edn. doi: 10.1081/E-ESS3-120053284.

Ghosh, P.K., Bandyopadhyay, K.K., Tripathi,
A.K., Hathi, K.M., Mandal, K.G., Mishra, A.K. 2003. Effect of integrated management of farmyard manure, phosphocompost, poultry manure and inorganic fertilizer for rainfed sorghum (Sorghum bicolor $\mathrm{L}$ ) in vertisol of central India. Ind. J. Agron., 48: 48-52.

Hepperly Paul, Lotter Don, Ulsh Christine Ziegler, Seidel Rita and Reider Carolyn. 2009. Compost, manure and synthetic fertilizer influences crop yields, soil properties, nitrate leaching and crop nutrient content, Compost Sci. Utilization, 17(2): 117-126.

Panse, V.G. and Sukhatme, P.V. 1989. Statistical method for agriculture workers, ICAR, New Delhi.

Roy, R.N. and Ange, A.L. 1991. In. Integrated plant nutrient systems (IPNS) and sustainable agriculture. Proc. FAI Annual Seminar, FAI, New Delhi, pp SV/1- 1/112.

Sanjivkumar, V. 2014. Effect of integrated nutrient management on soil fertility and yield of maize crop (Zea mays) in Entic Haplustart in Tamil Nadu, India. J. Appl. and Nat. Sci., 6(1): 294-297.

Singh, R.B. 2000. Environmental consequences of agricultural development: a case study from the green revolution state of Haryana, India, Agric., Ecosystem and Envir., 82(1-3): 97-103.

Teterwal, J.P., Ram, B., Meena, D.S. 2011. Effect of INM on productivity, profitability, nutrient uptake and soil fertility in rainfed maize (Zea mays). Ind. J. Agron., 56: 373-376.

Vanlawe, B., Diets, J., Sanginga, N. and Merckx, R. 2002. Integrated plant nutrient management in Sub-Saharan Africa: From Concept to practice. Nallingford, U.K: CABI Publishing.

\section{How to cite this article:}

Haribhushan Athokpam, R.S. Telem and S.H. Wani. 2017. Integrated Nutrient Management for Sustainable Maize (Zea mays L.) Production in Acidic Soil of Senapati District, Manipur, India. Int.J.Curr.Microbiol.App.Sci. 6(7): 690-695. doi: https://doi.org/10.20546/ijcmas.2017.607.085 